\title{
PERSPECTIVES ON REGENERATION OF ALVEOLAR BONE DEFECTS
}

\author{
Ljupcho Efremov ${ }^{1}$, Tatjana Kanjevac ${ }^{2}$, Dušica Ciric $^{2}$ and Darko Bosnakovski ${ }^{1}$ \\ ${ }^{1}$ Faculty of Medical Science, University Goce Delcev, Stip, R. Macedonia \\ ${ }^{2}$ Faculty of Medical Science, University of Kragujevac, Kragujevac, Srbija

\section{PERSPEKTIVE U REGENERACIJI ALVEOLARNIH KOŠTANIH DEFEKATA}

\author{
Ljupčo Efremov ${ }^{1}$, Tatjana Kanjevac ${ }^{2}$, Dušica Ćirić ${ }^{2}$ Darko Bosnakovski ${ }^{1}$ \\ ${ }^{1}$ Fakultet medicinskih nauka, Univerzitet Goce Delčev, Štip, RepublikaMakedonija \\ ${ }^{2}$ Fakultet medicinskih nauka, Univerzitet Kragujevac, Kragujevac, Srbija
}

\section{ABSTRACT}

Bone atrophy of the alveolar process is an important parameter in patients undergoing dental implants. There are several methods for preserving the alveolar process, with the autologous bone graft as the gold standard. Other approaches include the use of allografts, xenografts and synthetic bone grafts.

In recent years, the use of stem cells has increased in importance. The most common type of stem cells used are mesenchymal stem cells from various sources, including bone marrow, adipose tissue and dental pulp. The discovery of induced pluripotent stem cells and the continued research on embryonic stem cells open new possibilities in this field.

However, further research is needed to optimise protocols for isolation, differentiation and transplantation of cells with or without appropriate scaffolds, and to determine the correct clinical and therapeutic implications.

Keywords: alveolar process atrophy, bone grafts, scaffolds, stem cells.

\section{INTRODUCTION}

Surgical repair of bone defects remains a major challenge for orthopaedic, reconstructive, dental and craniofacial surgeons, and usually occurs after a traumatic experience. The loss of bone can also occur from infection, neoplasm and congenital disorders.

An important concern in dental medicine are defects that materialise after tooth extraction. Tooth extraction is one of the most common procedures, arising from several conditions, such as severe tooth decay, fractures, periodontal diseases and endodontic lesions. The periodontium is a complex tissue composed mainly of periodontal ligament tissue (PDL), gingival tissue, alveolar bone and cementum. PDL has a deposit of somatic stem cells that could reconstruct the periodontium, although its use in bone recon-

\section{SAŽETAK}

Atrofija alveolarnog nastavka važan je parametar prilikom planiranja postupka ugradnje stomatoloških implantata. Postoji više načina za očuvanje alveolarnog nastavka, pri čemu se autologni koštani graft smatra zlatnim standardom. Ostali pristupi očuvanja alveolarnog nastavka uključuju upotrebu alograftova, ksenograftova i sintetičkih koštanih graftova.

Poslednjih godina sve više dobija na značaju upotreba matičnih ćelija u ove svrhe. Najčešće korišćeni tip matičnih ćelija jesu mezenhimalne matične ćelije izolovane iz različitih izvora, kao što su koštana srž, masno tkivo i zubna pulpa. Otkriće indukovanih pluripotentnih matičnih ćelija, kao $i$ dalja istraživanja embrionalnih matičnih ćelija, otvaraju nove mogućnosti u ovoj oblasti.

Međutim, neophodna su dalja istraživanja da bi se optimizovali protokoli za izolaciju, diferencijaciju i transplataciju matičnih ćelija sa ili bez upotrebe odgovarajućih skafolda $i$ da bi se utvrdile njihove tačne kliničke i terapijske indikacije.

Ključne reči: atrofija alveolarnog nastavka, koštani graftovi, skafold, matične ćelije. struction is still the period under investigation. For successful implant placement into sites with missing dental units, adequate bone regeneration becomes vital in patient management.

\section{Alveolar process and dimensional changes of post-} extraction sockets

The main aim of management is to prevent alveolar process atrophy, that can occur after tooth removal. This atrophy starts developing during tooth eruption. The alveolar process supports the tooth socket and begins to resorb following tooth loss [1]. The volume and shape of the alveolar process is determined by the tooth formation, axis 
of eruption and eventual inclination [2]. From early studies by Amler et al., we have a detailed description of unassisted histological healing of alveoli in healthy humans [3]. When a tooth is removed, a clot forms and is gradually replaced by granulation tissue in the base and the periphery of the alveolus. After the first week, new bone formation is evident, with the osteoid matrix at the alveolus base as noncalcified bone spicules. In 38 days, this osteoid starts to mineralise from the alveolus base in a coronal direction, filling two-thirds of the alveoli. At this point, the first sign of a progressive resorption of the alveolar crest occurs. This process is followed by a continuous re-epithelialisation, which completely covers the socket 6 weeks after extraction. After additional bone fill develops, a maximum radiographic density is achieved around the hundredth day.

The usual outcome after tooth extraction includes is a reduction in the dimensions of the socket due to pathologic and traumatic processes that damage the bone walls of the socket. According to Araujo and Lindhe, notable osteoclastic activity occurred during the first eight weeks after tooth extraction, resulting in resorption of the crestal regions of both the buccal and lingual bone walls [4]. If fibrous tissue invades the empty socket, normal healing and osseous regeneration would be prevented, causing problems for future dental implants [5].

\section{Alveolar process atrophy}

Along with an incomplete healing of the socket, progressive bone resorption commences along the residual alveolar process. A reduction in both horizontal and vertical directions has been observed over a 12-month period, with a predominant reduction occurring during the first 3 months. This continual resorption leads to a narrower and shorter alveolar process [6]. Due to this effect, the alveolar process makes a positional change to a more palatal/lingual position. A study showed that the clinical loss in width (3.87 $\mathrm{mm}$ ) is greater than the loss in height, as assessed both clinically $(1.67-2.03 \mathrm{~mm})$ and radiographically $(1.53 \mathrm{~mm})$ [2]. With bone grafting techniques, the horizontal and vertical dimensions of the alveolar process can be preserved.

While alveolar atrophy is not a concern for most dentist and surgeons, knowledge about the healing process at the extraction sites, including the change in contour, as caused by bone resorption, is needed for treatment planning. In an effort to restore aesthetics and mastication function, procedures for bone regeneration by filling the extraction sockets have been developed. This has resulted in a satisfactory alveolar process height and width, thus providing sufficient alveolar bone volume for dental implants.

\section{BONE GRAFTS}

During dental procedures, large bone defects can be created, which can cause problems associated with aesthetics, function, the healing process, and even jaw bone stability. The application of several materials to the area around these bony defects aids bone regeneration and eliminates the defects or limits their size. These materials may also prove useful in the regeneration of periodontal tissues, the filling of bone defects around an implant, and the augmentation of a deficient alveolar ridge [7].

Bones can regenerate from bone grafts. Bone grafting is a surgical procedure that replaces missing bone with material from the patient's own body, or from an artificial, synthetic or natural substitute. As natural bone grows, the graft material is usually completely replaced, resulting in a fully integrated region of new bone. Clinical outcomes of bone grafting depend on the bone defect and extension, structural properties of the grafting material and the immunologic reaction of the host [8].

The bone grafts should be sterile, non-toxic, non-antigenic, biocompatible and easy to use. Other important properties of bone grafts include the following [9-12]: 1. Oosteointegration (This is the ability to chemically bond to the surface of bone without an intervening layer of fibrous tissue); 2. Osteoconduction (this is the ability to support the growth of bones as a scaffold on which bone cells can proliferate; osteoblasts from the margin of defect are grafted and utilised as the bone graft material as a framew ork upon which to spread and generate new bone); 3. Oosteoinduction (This is the ability to induce proliferation and differentiation of the MSCs from surrounding tissues to an osteoblastic phenotype; Stimulating the osteoprogenitor cells to differentiate into osteoblasts is needed, which begins the formation of new bone); 4. osteopromotion (This is the enhancement of osteoinduction without having any of the osteoinductive properties); and 5. Osteogenesis (Tthe graft material is a reservoir of MSCs and progenitor cells that can form new bone). The interaction between the graft and the surrounding host bone is very important and is the subject of many researchers. Although some grafts will merely act as space fillers, the ideal graft will be osseoconductive and osseoinductive [13].

Bone formation is a complex process that begins with the recruitment and proliferation of osteoprogenitor cells that are then differentiated into osteoblasts, with subsequent osteoid formation and matrix mineralisation. Their ability to attach to a scaffold surface is an important part in the development of new tissue. An ideal bone graft augments this osseous healing by providing a cellular milieu for new bone formation and a structural framework during healing [14]. A bone graft should not support local pathogens or cross-infection and should be resorbable, microporous and easy to handle.

Cancellous grafts have the highest concentration of osteogenic cells, and the particulate form of these grafts has the greatest cell survival ability, due to better diffusion and rapid revascularisation. These grafts must completely undergo a two-phase mechanism of graft healing. Osteoblasts that survive transplantation proliferate and form osteoid. This process is active in the first 2 to 4 weeks, 
and the definitive amount of bone formed is related to the quantity of osteoid formed in phase one. Phase two starts at around the second week after grafting, and although it peaks in intensity at approximately 4 to 6 weeks, it continues until the graft matures. The initiation of phase two is marked by osteoclastic cell activity within the graft. Osteoclasts remove minerals, forming Howship's lacunae along the trabeculae. This resorptive process exposes the extracellular matrix of the bone, which is the natural location of the bone-inductive glycoprotein (BMP). Exposure of BMP initiates an inductive process characterised by chemotaxis of the mesenchymal stem cells, proliferation of cells in response to mitogenic signals, and differentiation of cells into osteoblasts. Inducible cell populations may be local or distant from the graft site.

Examples of local cell populations that may contribute to the graft include osteoprogenitor cells in the graft endosteum, stem cells of the transplanted marrow, or cells in the cambium layer of adjacent periosteum. Additional inducible pluripotent cells may arrive at the graft site with budding blood vessels. During phase two, there is progressive osteoclastic resorption of phase one osteoid and nonviable graft trabeculae. This continues to expose BMP, which perpetuates the differentiation of osteoblasts, leading to the formation of mature vascular osteocyte-rich bone [15]. Based on their bone of origin, grafts can be divided into four categories: autografts, allografts, alloplastic grafts and heterografts [16].

\section{Autologous bone grafts (autografts)}

The treatment of bone defects and preservation of the socket include autografting and allografting cancellous bone. The intraoral or extraoral autogenous bone graft is readily available and is the first choice of bone grafting material for many clinicians. Autologous bone grafting usually harvests bone from the non-essential bones, such as the iliac crest, mandibular symphysis or anterior mandibular ramus, maxilla, cranium, tibial plateau and ribs. The shape, form, and volume of the graft procured are linked to the defect to be reconstructed. This is considered as a gold standard. Essentially, this graft has less risk of graft rejection or other immunological resistance, provides a scaffold for osteoconduction, growth factors for osteoinduction and progenitor cells for osteogenesis, and permits a fast angiogenic in-growth of vessels $[17,18]$. The main advantages of autogenous bone graft are biocompatibility, sterility and availability. However, there are several limitations, including limited availability of bone, high surgery cost and post-operational morbidity, such as blood loss, wound complications and chronic pain.

All bones require blood supply in the transplanted site. Depending on the transplant site and graft size, an additional blood supply may be required. For these types of grafts, the extraction of the periosteum parts and accompanying blood vessels with the donor bone is required. This kind of graft is known as a free flap graft [8].

\section{Allogenic bone grafts (allografts)}

Allografts are an alternative to autografts. Different sources for bone harvesting can be used, such as and includebone from living or post-mortem donors. The graft may be fresh or fresh-frozen bone, freeze-dried allograft (FDBA) or decalcified freeze-dried bone allograft (DFD$\mathrm{BA}$ ) and is considered a good source of bone morphogenic protein. The American Association of Tissue Bank standards require that all donors be screened, serologic tests be performed, and all specimens be sterilised and verified by culture prior to release [13].

The increasing number of grafting procedures and the disadvantages of current autograft and allograft treatments (limited graft quantity, risk of disease transmission) drive the need for alternative methods to treat bone defects [19].

\section{Synthetic bone graft (alloplastic grafts)}

The use of synthetic bioactive bone substitute materials is of increasing importance in modern dentistry, as alternatives to autogenous or allogenic bone grafts. Due to the shortcomings of the decellularised, deproteinated, biological materials, the quest for a synthetic material with many of the properties of decalcified, decellularised bone has been conducted. Its positive attributes include avoiding a second surgical site with less risk for patient morbidity and minimal risk of transplant rejection. Their physical properties can be manipulated and may be used in combination with bonepromoting molecules to enhance the effect $[12,20]$. However, they possess only two properties of an ideal bone graft material, osteointegration and osteoconduction. Most synthetic bone grafts are biocompatible, show minimal fibrotic reaction, undergo remodelling and have similar strength to the cortical/cancellous bone being replaced.

Various alloplastic bone substitution materials of different origins, chemical composition, and structural properties have been investigated over the years. The materials commonly used are ceramics, polymers or composites. These alloplastic materials are either absorbable or non-absorbable and are naturally derived or synthetically manufactured [21]. Various types of biomaterials (minerals and non-mineral based materials and natural and artificial polymers) with different characteristics have been used to study ossification and bone formation. Calcium phosphate ceramics include a variety of ceramics, such as hydroxyapatite, tricalcium phosphate, and calcium phosphate cement. These mentioned ceramics have either excellent biocompatibility, bone bonding or bone regeneration properties [22].

\section{Xenogrograft (heterografts)}

Xenografts or heterografts are bone grafts from a species other than human, such as bovine bone, which can be freeze-dried or demineralised and deproteinised. Xenografts are usually only distributed as a calcified matrix. Attempts at xenograft transplantation (the transmission 
of living organs, tissues, or cells from one species to another) were first performed in the early twentieth century. Today, the relative shortage of human organs and tissue available for transplantation has amplified interest in xenografts as alternatives to human-tissue transplants. Xenografts are often used as scaffold and allow for ingrowth, and sometimes replacement, by host tissue while providing structural support for deficient tissue. Although the obvious advantage of xenotransplantation is the almost infinite amount of nonhuman animal tissue that might be considered for transplantation, its major disadvantage is the risk of cross-species disease transmission.

Of all the grafts, bone autografts give the best results. However their use is limited because a second concurrent surgical procedure is required. Therefore, the aforementioned synthetic substitute materials are used instead, and bone regeneration in areas with large bone defects is satisfactorily accomplished. Successful graft incorporation is defined as the ability of the graft and surrounding tissues to function and maintain mechanical integrity $[8,23]$.

\section{STEM CELLS}

One tissue engineering method proposes tissue regeneration with the help of molecules, cells or a combination of these with biocompatible materials to ensure support and enhance physiological healing processes. Tissue engineering may provide functional substitutes for native tissue to serve as grafts for implantation.

Cells are described as pluripotent if they can form all the cell types of the adult organism. These cells are embryonic stem (ES) cells and induced pluripotent stem (iPS) cells. Multipotent stem cells can form all the differentiated cell types of a given tissue, for example, mesenchymal stem cells. In some cases, a tissue contains only one differentiated lineage, and the stem cells that maintain the lineage are described as unipotent, for example, skin stem cells.

By definition, a stem cell is characterised by its ability to self-renew and to differentiate along multiple lineage pathways. Bone marrow contains a large population of multipotent stem cells that are undifferentiated, which are known as stromal cells or mesenchymal stem cells (MSCs). They can be differentiated into several cell types, including osteocytes, chondrocytes, adipocytes and hematopoieticsupportive stroma cells. This ability has been well proven. MSCs can be isolated from the bone marrow, cultured in vitro and implanted into bone defects to repair bone loss. These cells could be distinguished from the hematopoietic elements in the marrow by their high adherence to the substrate plastic in tissue culture flasks.

Historically, the use of MSCs in osteogenesis was initiated by Friedenstein et al. in the 1970s [24, 25] and later by Kuznetsov et al. in 1989 [26], who were among the first researchers experimenting with MSCs transplantation beneath the renal capsule in mice and creating growths in diffusion chambers in vivo in monolayer culture. Kuznets- ov et al. showed that bone formation was characterised with lamellar, long trabeculae and abundant haematopoiesis. However, this study was limited to kidney transplants. Goshima et al. (1991) postulated that a composite of MSCs and ceramics, used as a delivery vehicles for these cells, contributes to accelerated and massive osseous repair [27]. This was shown by harvesting bone marrow cells from rats that were later introduced into tissue culture, and then the cells were mitotically expanded, passaged and placed on small cubes of porous calcium phosphate ceramics. These samples were grafted in the subcutaneous sites of syngenic rats. Bone formation was observed as early as 2 weeks. The study concludes that while bone graft substitutes, such as calcium phosphate ceramics, are biocompatible and osteoconductive, ceramics do not induce bone formation. Only when such substitutes are combined with MSCs can bone formation be observed in the pore regions of the ceramics, in close association with the host vasculature. Kuznetsov et al. (1997) extended the experimentations by showing that individual human MSCs have osteogenic potential [28]. They transplanted human MSCs into the subcutaneous space of immunodeficient mice within vehicles containing hydroxyapatite-tricalcium phosphate ceramic and then proved that after 8 weeks, the transplants derived their bone from the human donor cells. Currently, this type of experiment is regular procedure for evaluating the osteogenic potential of stem cells in vivo [29].

The characteristics of an optimal stem cell include the following: no immunorejection, no graft-versus-host disease, no tumorigenicity, immediate availability, availability in pertinent quantities, controlled cell proliferation rate, predictable and consistent osteogenic potential, and controlled integration into the surrounding tissue[10].

MSCs have been shown to heal bone defects in an autologuous setting. Allogenic donor-derived MSCs present an attractive alternative to using autologuous cells. By using donor-derived cells, the need for harvesting and expanding cells for each patient is eliminated. Because billions of cells may be expanded from an individual donor, many devices can be created from rigorously tested and qualified cells. An allogenic MSC-based bone regeneration constructs for the augmentation and repair of alveolar bone were developed by several researchers. As demonstrated by a longterm study, the histological evaluation of grafts in human mandibles after three years show that the regenerated bone is qualitatively a compact type, rather than a cancellous (spongy) type that is physiological for the area. This was explained by the fact that grafted stem cells did not follow the local signals of the surrounding spongy bone [30]. New research shows that low-intensity pulsed ultrasound stimulation could be a positive influence on osteogenic differentiation of the human alveolar bone-derived mesenchymal stem cells, that can be used in tooth tissue engineering [31]. However, as some studies claim, researchers with MSCs need to establish more predictable outcomes and better long-term prognosis to be considered a firstchoice treatment [32-35]. 
An alternative to bone marrow-derived mesenchymal stem cells are the periodontal ligament stem cells (PDLSc) and the dental follicle cells (DFCs), which represent a new approach in reconstructive dentistry for the treatment of damaged periodontium. Restoration of lost periodontium is a challenge because alveolar bone, cementum and periodontal ligament need to be restored to their original form. More research is needed to explore their true potential, although some progress has been made by several research groups [36-40].

\section{THE IMPORTANCE OF SCAFFOLDS}

The number of surgical procedures correcting bone defects use autografts, allografts or metallic and ceramic implants, each with its own drawbacks, including donor site morbidity, pathogen transmission, and mismatching material properties with the native bone, respectively. As an alternative to these procedures, tissue engineering has emerged to create de novo tissue by growing cells on three-dimensional (3D) scaffolding [41, 42]. Scaffolds play an important role in dental regenerative medicine because conventional tissue replacements, such as autografts and allografts, have a variety of problems that cannot satisfy high performance demands necessary for today's patients. Bone is a nanocomposite that consists of a protein-based soft hydrogel template (collagen, non-collagenous proteins (laminin, fibronectin, and vitronectin), water and hard inorganic components $(70 \%$ of the bone matrix is composed of nanocrystalline hydroxyapatite). This self-assembled nanostructured extracellular matrix (ECM) in bone closely surrounds and affects the mesenchymal stem cells, osteoblasts, osteoclasts and fibroblast adhesion, proliferation and differentiation [43].

Investigators are searching for the "ideal scaffold" to facilitate the growth, integration and differentiation of stem cells [44]. The best scaffold for engineered tissue should be the ECM of the target tissue in its native state because ECM components specifically modulate MSC adhesion, migration, proliferation and osteogenic differentiation $[45,46]$. Scaffolds are artificial structures that should mimic the morphologic structures and function of the surrounding tissue. Scaffolds allow cell attachment and migration, deliver and retain cells and biochemical factors, enable diffusion of the vital cell nutrients and expressed products [47].

Cell and tissue response to a scaffold depends upon the composition of the scaffold, its surface microstructure, and three-dimensional architecture. Scaffolds should provide void volume for vascularisation and new tissue formation during remodelling, provide the shape and mechanical stability to the tissue defect and provide rigidity and stiffness to the engineered tissues [45]. Appropriate porosity and pore structure is needed to accept and organise the types of cells and tissues that regenerate [48]. Mechanical properties that are appropriate for the cells and their macro- and microenvironments are also needed. The cellular microenvironment at the interface between tissue and scaffold is extremely important and must be created to either recruit cells into the scaffold or allow cells to be seeded or transplanted for repair. Scaffolds allow cell attachment and migration, deliver and retain cells and biochemical factors, enable diffusion of the vital cell nutrients and expressed products, and should promote healing and should be easily fabricated [49-51].

Biocompatibility is of the utmost importance to prevent adverse tissue reactions. Because the host cells will interact with the scaffold, biodegradability is a must to facilitate constructive remodelling, which is characterised by scaffold degradation, cellular infiltration, vascularisation, differentiation and spatial organisation of the cells, and replacement of the scaffold by the appropriate tissues [52]. Material scientists can now fabricate biocompatible scaffolds with a wide range of physical parameters, combining mechanical integrity with high porosity to promote cell infiltration and angiogenesis. Currently proposed scaffolds include those made of inorganic materials, organic or synthetic polymers, or mixed materials (composite scaffolds). These materials include natural polymers (collagen, chitin, alginate), synthetic polymers (Polyglycolic acid (PGA), Poly (lactic-co-glycolic acid) (PLGA), Poly (lactic acid) (PLA)), metals (titanium, nitinol), and ceramics, such as calcium phosphates (hydroxyapatite, tricalcium phosphate], calcium sulphates, and biological glass $[52,53]$. The biomaterials need to be compatible with the biomolecules and amenable to an encapsulation technique for controlled release of the biomolecules with retained bioactivity [45]. Natural materials offer a high degree of structural strength, are compatible with cells and tissues and biodegradable, but are often difficult to process and afflicted with the risk of transmitting animal-associated pathogens or provoking an immunoresponse. Synthetic polymers provide excellent chemical and mechanical properties and allow greater control over the physicochemical characteristics, such as molecular weight, configuration of polymer chains, and the presence of functional groups. Hydrogels offer numerous properties including high biocompatibility, a tissue-like water content and mechanical characteristics similar to those of native tissue. An ideal scaffold should combine the best properties of each of these groups of biomaterials $[44,54,55]$.

Experiments with cell-free scaffolds are especially attractive because they have an easier handling process that eliminates the issues associated with the use of stem cells, their expansion in vitro, storage and shelf-life, cost, the immunoresponse of the host and transmission of diseases $[53,56]$. However there are some disadvantages in this method: the cells may have low survival rates, the cells might migrate to different locations within the body, leading to aberrant mineralisation patterns. A solution may be to apply the cells together with a scaffold. This would help to position and maintain cell localisation $[53,57]$.

The paradigm of bone tissue engineering procedures is in the isolation and expansion of mesenchymal stem cells (MSCs) from the patients and their seeding onto porous biodegradable matrices, and scaffolds. Scaffold morphol- 
ogy, in terms of interconnectivity, pore-size and shape is a crucial point for stem cell-biomaterial interaction. High porosity and adequate pore-size are necessary properties for increasing the surface area available for cell attachment and tissue in-growth in order to facilitate the uniform distribution of cells and the adequate transport of nutrients. Small pores on the macropore surface of the scaffolds may also be helpful to improve the biological performance of the porous scaffolds and promote more favourable bioresorption of the material [50,58].

During the in vitro culture period, stem cells are generally exposed to signalling molecules (growth factors and other osteoinductive molecules), supplied as soluble factors and/or released by the scaffold, to drive MSCs toward the osteogenic lineage differentiation. This engineered tissue is implanted into the damaged site to regenerate the new bone as the scaffold degrades [59]. Implantation of in vitro-expanded MSCs within the appropriate scaffold resulted in bone regeneration in various animal models. The supporting scaffold plays a very important part by providing an anchorage point for cells.

The use of scaffolds with different types of particles offers the advantage of perfectly adapting to the shape of the defect without interfering with the vascularisation process. Biological granular scaffolds can stimulate vascularisation and tissue integration because of the appropriate spaces between the particles of the inorganic material. Using granular material also accelerates the scaffold resorption process and the replacement of the inorganic material with newly formed bone. Scaffolds containing crystalline beta-tri-calcium phosphate have been proven to lack local and systemic toxicity. Its granular consistency provide an optimal osteoconductive environment for the development of bone tissue. Tricalcium phosphate is extremely hydrophilic, making it easily insertable inside the defect. Tri calcium phosphate scaffolds ensure rapid resorption, which is an advantage for small and medium size defects, and they also release calcium and phosphate ions, assuring rapid mineralisation of the newly formed tissue.

Porous ceramic scaffolds have already been noted as the most suitable material for reproducing the structural integrity of ossified tissues. When combined with the bioactive attributes of calcium phosphate, hydroxyapatite, bioactive glass, or other similar ceramics, the composite material can support progenitor cells and mimic the natural characteristics of bone [52].

\section{LATEST RESULTS AND ACHIEVEMENTS}

The emerging field of regenerative medicine will require a reliable source of stem cells, biomaterial scaffolds and cytokine growth factors. One study showed massive bone formation when autologous mesenchymal stem cells placed on TCP scaffolds were implanted in the alveolar sockets on a rat animal model. This study used a large number of osteoprogenitor cells on a scaffold, which has proven to accelerate the osteogenesis process, and showed that a concentration of $5 \times 10^{4}$ cells $/ \mathrm{ml}$ can induce bone formation, whereas a concentration of $0,5-1 \times 10^{6}$ cells/ $\mathrm{ml}$ did not show satisfactory results. The study concludes that implantation of autologous mesenchymal stem cells on specific scaffolds will augment bone repair [60]. New studies have suggested that transplanted bone-marrow derived MSCs can deliver new mitochondria to damaged cells, thereby rescuing the aerobic metabolism [61].

Adipose tissue represents an alternative source of adult stem cells with the ability to differentiate along multiple lineage pathways. To identify this isolated, plastic-adherent, multipotent cell population, these cells are called adiposederived stem cells (ASCs) according to the International Fat Applied Technology Society. The evidence supporting the claims that adipose tissue contains multipotent progenitor cells start from an inborn metabolic error, the progressive osseous heteroplasia $(\mathrm{POH})$, where ectopic bone can be formed within the subcutaneous adipose layer of the skin in children. Histological analysis shows the presence of osteoblasts, chondrocytes and adipocytes. This implies that adipose-derived stem cell can differentiate along adipogenic, chondrogenic and osteogenic lineages.

Adipose tissue derives from the mesodermal layer of the embryo and develops both pre- and postnatally. Macroscopically, at least 5 different types of adipose tissue exist: bone marrow, brown, mammary, mechanical and white [62]. A study showed that in humans, subcutaneous white adipose tissue in the arm had a greater number of stem cells compared to the thigh, abdomen and breast [63]. The ASCs maintain their telomere length with progressive passage in culture, however with prolonged passage for more than 4 months, human ASCs can undergo malignant transformation [64]. The greatest advantage of using ASCs is that it can be obtained repeatedly in large quantities under local anaesthesia with minimal patient discomfort.

Beside autologous ASCs, the use of allogeneic ASCs is also important. Studies have demonstrated that the passage of human ASCs reduces the expression of surface histocompatibility antigens and no longer stimulates a mixed lymphocyte reaction when co-cultured with allogeneic peripheral blood monocytes $[65,66]$. This profoundly affects the field of regenerative medicine. A study showed that after a 3 month healing period, the addition of ASCs to plateletrich plasma (PRP) enhanced the amount of $n$-ewly formed dog alveolar bone [67], and other studies came to thesimilar conclusions $[68,69]$. One study compared the use of ASCs and autogenous bone grafts in dogs, bone formation in the maxillary alveolar cleft was higher in the autograft group [70]. More long-term experiments examining the safety of ASCs transplantation in appropriate animal models are required before advanced studies in patients.

Another potential source for tissue engineering is embryonic stem cells (ESCs). They are harvested from the inner cell mass of blastocysts. Their pluripotent characteristics enable unlimited self-renewal and differentiation into all cell types. A challenge that needs to be addressed is their tumorigenic potential. Therefore, removing the re- 
maining undifferentiated ES cells from the newly formed tissue before implantation is crucial. Further research is needed to develop efficient methods to direct ES cells into therapeutically desired cell lineages, such as osteoblast, while eliminating the pluripotent cells.

The latest trend in tissue engineering is using nuclear reprogramming to convert a somatic cell type into a different, unrelated one through a switch of the gene expression pattern, resulting in the generation of an embryonic stem cell-like pluripotent cells by ectopic overexpression of only four genes in human fibroblasts. These cells are called induced pluripotent stem cells (iPSCs) [71-73]. This research showed that somatic cells, such as fibroblasts or adipocytes, can be directly converted to clinically relevant cell types after ectopic delivery of factors which are involved in the embryonic development of the targeted cell type. The assumption is that factors responsible for the maintenance of the pluripotent state in embryonic stem cells (ESCs) could induce pluripotency in somatic cells after ectopic overexpression. Kazutoshi Takahashi and Shinya Yamanaka identified four factors Oct4, Sox2, Klf4 and c-Myc as being sufficient to reprogram mouse embryonic fibroblasts (MEFs) into a morphology highly comparable with embryonic stem cells, which they named iPSCs [74]. iPSCs could maintain their self-renewal when cultured under ESC conditions and differentiate into cells of all three germ layers [75-77], which proved that they are nearly indistinguishable from ESCs. More recent investigations convincingly support the osteogenic potential of hESCs and iPSCs in vivo [78, 79]. Arpornmaeklong and co-workers derived MSCs from the hESC line BG01, characterised by the expression of MSCspecific surface antigens, and further differentiating them into adipogenic, chondrogenic and osteogenic tissue [78].

Transplanting iPS cells uses the patient's own cells, eliminating the need for immunosuppression. Discovering how the pluripotent state can be efficiently induced and maintained by treating cells with pharmacologically active compounds, rather than genetic manipulation, is an important goal [80].

As new surgical techniques develop for replacing nonfunctional tissues or organs, the need for more artificial means of organ transplants or tissue regeneration will arise. A well-defined pathology, such as alveolar bone atrophy, requires further advances in the field of bone regeneration using stem cells to generate new tissue or regenerate residual tissue. Development in this field will benefit several branches in medicine and dentistry. Techniques for improved growth rate, extent and strength of n-ewly formed bone must be developed in concordance with increased clinical application. Most importantly, researchers need to ensure that any tumorigenic potential is eliminated.

\section{CONCLUSION AND FUTURE DIRECTIONS}

Bone tissue engineering can overcome the drawbacks of traditional bone graft materials and offers a novel way for bone repair and regeneration. Scientists have been ac- tively investigating the ideal cell source to regenerate and repair bone for the last four decades. More than $300 \mathrm{ar}-$ ticles [81] on bone regeneration using stem cells in animal models have been published. However, only a few studies include human subjects [82]. MSCs derived from the adult bone marrow provide an exciting and promising stem cell population for bone repair. The disadvantages of MSCs are the limited availability of cells for therapy and the nonspecific cell surface markers. Therefore, specific markers need to be identified for easier detection in laboratories. $\mathrm{E}$ SCs are also a potential source and have an additional advantage of unlimited division and pluripotency. However a reproducible protocol to ensure that ESCs differentiate into functional bone needs to be developed.

ESCs studies need to overcome ethical issues, immune responses and tumorigenic potential. ESCs represent an innovative treatment for many disease conditions, but still require rigorous evaluation for use in clinical applications. IPS cells are currently the most exciting and promising cell population, with ASCs a close second. Both cells populations are at the apex of their popularity within the scientific community, as a supply of readily available cells can truly push the field of regenerative medicine. The field of regenerative medicine should not be entrenched in only stem cells but also expand knowledge in the use of bone grafts and scaffolds. This should be used in a complementary way, if we strive for maximum results in the treatment of diseases.

\section{REFERENCES}

1. Pietrokovski J, et al. Morphologic characteristics of bony edentulous jaws. J Prosthodont 2007; 16: 141-7.

2. Van der Weijden F, Dell'Acqua F, Slot DE. Alveolar bone dimensional changes of post-extraction sockets in humans: a systematic review. J Clin Periodontol 2009; 36: 1048-58.

3. Amler MH, Johnson PL, Salman I. Histological and histochemical investigation of human alveolar socket healing in undisturbed extraction wounds. J Am Dent Assoc 1960; 61: 32-44.

4. Araujo MG, Lindhe J. Dimensional ridge alterations following tooth extraction. An experimental study in the dog. J Clin Periodontol 2005; 32: 212-8.

5. Chen ST, Wilson TG Jr, Hammerle CH. Immediate or early placement of implants following tooth extraction: review of biologic basis, clinical procedures, and outcomes. Int J Oral Maxillofac Implants 19 Suppl 2004; $12-25$.

6. Pinho MN et al. Titanium membranes in prevention of alveolar collapse after tooth extraction. Implant Dent 2006; 15: 53-61.

7. Howe WR, Dellavalle R, Vitamin D deficiency. N Engl J Med 2007; 357: 1981; author reply 1981-2.

8. Kumar P, Vinitha B, Fathima G. Bone grafts in dentistry. J Pharm Bioallied Sci 2013; 5: 125-7. 
9. Moore WR, Graves SE, Bain GI. Synthetic bone graft substitutes. ANZ J Surg 2001; 71: 354-61.

10. Logeart-Avramoglou D, et al. Engineering bone: challenges and obstacles. J Cell Mol Med 2005; 9: 72-84.

11. Giannoudis PV, Dinopoulos H, Tsiridis E. Bone substitutes: an update. Injury 2005; 36 Suppl 3: 20-7.

12. Misch CE, Dietsh F. Bone-grafting materials in implant dentistry. Implant Dent 1993; 2: 158-67.

13. Palmer R, Smith B, Howe L, Palmer P. Implants in clinical dentistry. Taylor and Francis e-Library 2002; 131-133.

14. Beaman FD, et al. Bone graft materials and synthetic substitutes. Radiol Clin North Am 2006; 44: 451-61.

15. Peterson, L.J., Peterson's Principles of Oral and Maxillofacial Surgery. 2nd ed. BC Decker, 2004.

16. Fragiskos FD. Oral Surgery. Springer, 2007.

17. Dimitriou R, Jones E, McGonagle D, Giannoudis PV. Bone regeneration: current concepts and future directions. BMC Medicine 2011; 9: 66-76.

18. Arrington ED, Smith WJ, Chambers HG, Bucknell AL, Davino NA. Complications of iliac crest bone graft harvesting. Clin. Orthop. 1996; 329, 300-309.

19. Giannoudis PV, Pountos I. Tissue regeneration. The past, the present and the future. Injur 2005; 36 Suppl 4: 2-5.

20. Shegarfi H, Reikeras O. Bone transplantation and immune response. Journal of Orthopaedic Surgery 2009; 17: 206-11.

21. Burg KJ, Porter S, Kellam JF. Biomaterial developments for bone tissue engineering. Biomaterials 2000; 2: 2347-2359.

22. Kunert-Keil C, Gredes T, Gedrange T. Biomaterials Applicable for Alveolar Sockets Preservation: In Vivo and In Vitro Studies In book: Implant Dentistry - The Most Promising Discipline of Dentistry 2011.

23. Afzali B, Lechler RI, Hernandez-Fuentes MP. Allorecognition and the alloresponse: clinical implications. Tissue Antigens 2007; 69: 545-56.

24. Friedenstein AJ, Chailakhjan RK, Lalykina KS. The development of fibroblast colonies in monolayer cultures of guinea-pig bone marrow and spleen cells. Cell Tissue Kinet 1970; 3: 393-403.

25. Friedenstein AJ, et al. Stromal cells responsible for transferring the microenvironment of the hemopoietic tissues. Cloning in vitro and retransplantation in vivo. Transplantation 1974; 17: 331-40.

26. Kuznetsov SA, Grosheva AG, Fridenshtein A. Osteogenic properties of adhesive cells in Dexter culture of the mouse bone marro. Biull Eksp Biol Med 1989; 108: 236-8.

27. Goshima J, Goldberg VM, Caplan AI. Osteogenic potential of culture-expanded rat marrow cells as assayed in vivo with porous calcium phosphate ceramic. Biomaterials 1991; 12: 253-8.

28. Kuznetsov SA, et al. Single-colony derived strains of human marrow stromal fibroblasts form bone after transplantation in vivo. J Bone Miner Res 1997; 12: 1335-47.

29. Gang EJ, et al. SSEA-4 identifies mesenchymal stem cells from bone marrow. Blood 2007; 109: 1743-51.
30. Giuliani A, et al. Three years after transplants in human mandibles, histological and in-line holotomography revealed that stem cells regenerated a compact rather than a spongy bone: biological and clinical implications. Stem Cells Transl Med 2013; 2: 316-24.

31. Lim K, et al. In vitro effects of low-intensity pulsed ultrasound stimulation on the osteogenic differentiation of human alveolar bone-derived mesenchymal stem cells for tooth tissue engineering. Biomed Res Int 2013; 2013: 269724.

32. Jakobsen C, et al. Mesenchymal stem cells in oral reconstructive surgery: a systematic review of the literature. J Oral Rehabil 2013; 40: 693-706.

33. Trofin EA, Monsarrat P, Kemoun P. Cell therapy of periodontium: from animal to human? Front Physiol 2013; 4: 325.

34. Zigdon H, Levin L. Stem cell therapy for bone regeneration: present and future strategies. Alpha Omegan 2012; 105: 35-8.

35. Zhang Z. Bone regeneration by stem cell and tissue engineering in oral and maxillofacial region. Front Med 2011; 5: 401-13.

36. Maeda $\mathrm{H}$, et al. Promise of periodontal ligament stem cells in regeneration of periodontium. Stem Cell Res Ther 2011; 2: 33.

37. Iwata $\mathrm{T}$, et al. Tissue engineering in periodontal tissue. Anat Rec (Hoboken) 2014; 297: 16-25.

38. Mrozik KM, et al. Regeneration of periodontal tissues using allogeneic periodontal ligament stem cells in an ovine model. Regen Med 2013; 8: 711-23.

39. Khorsand A, et al. Autologous dental pulp stem cells in regeneration of defect created in canine periodontal tissue. J Oral Implantol 2013; 39: 433-43.

40. Chen FM, et al. Stem cell-delivery therapeutics for periodontal tissue regeneration. Biomaterials 2012; 33: 6320-44.

41. Smith LA, et al. The influence of three-dimensional nanofibrous scaffolds on the osteogenic differentiation of embryonic stem cells. Biomaterials 2009; 30: 2516-22.

42. Bosnakovski D, et al. Chondrogenic differentiation of bovine bone marrow mesenchymal stem cells (MSCs) in different hydrogels: influence of collagen type II extracellular matrix on MSC chondrogenesis. Biotechnol Bioeng 2006; 93(6): 1152-63.

43. Zhang L, Webster JT. Nanotechnology and nanomaterials: Promises for improved tissue regeneration. Nano Today 2009; 4: 66-80.

44. Rodríguez-Lozano FJ, et al. Mesenchymal dental stem cells in regenerative dentistry. Med Oral Patol Oral Cir Bucal. 2012; 17: 1062-7.

45. Chan BP, Leong W. Scaffolding in tissue engineering: general approaches nd tissue-specific considerations. Eur Spine J 2008, 17 Suppl 4: 467-479.

46. Egusa H, et al. Stem cells in dentistry - Part II: Clinical applications. Journal of Prosthodontic Research 2012; 56: 229-248. 
47. Martino S, Francesco D’Angelo F, Armentano I, Kenny JM, Orlacchio A. Stem cell-biomaterial interactions for regenerative medicine. Biotechnology Advances 2012; 30: 338-51.

48. Chen Q, Roether JA, Boccaccini AR. Tissue Engineering Scaffolds from Bioactive Glass and Composite Materials. Topics in Tissue Engineering 2008; 1-27.

49. Basu B, Katti D, Kumar A. Advanced Biomaterials: Fundamentals, Processing and Applications. John Wiley \& Sons, Inc., USA, 2009.

50. Mitra J,Tripathi G, Sharma A, Basu B. Scaffolds for bone tissue engineering: role of surface patterning on osteoblast response. RSC Adv. 2013, 3: 11073-11094.

51. Yuan $\mathrm{H}$, et al. A preliminary study on osteoinduction of two kinds of calcium phosphate ceramics. Biomaterials 1999; 20: 1799-806.

52. Galler KM, D’Souza RN, Hartgerink JD, Schmalz G. Scaffolds for Dental Pulp Tissue Engineering. Adv Dent Res 2011; 23: 333-339.

53. Zaidman N, Bosnakovski D. Advancing with Ceramic Biocomposites for Bone Graft Implants. Recent Patents on Regenerative Medicine 2012; 2: 65-72.

54. Galler KM, D’Souza RN. Tissue engineering approaches for regenerative dentistry. Regen Med 2011; 6:111-24.

55. Willerth SM, Sakiyama-Elbert SE. Combining stem cells and biomaterial scaffolds for constructing tissues and cell delivery. (accessed in december 2013. at http:// www.stembook.org/node/450)

56. Laino G. et al. An approachable human adult stem cell source for hard-tissue engineering. J Cell Physiol 2006; 206: 693-701.

57. Murray PE, Garcia-Godoy F, Hargreaves KM. Regenerative endodontics: a review of current status and a call for action. J Endod 2007; 33: 377-90.

58. Salgado AJ, Coutinho OP, Reis RL. Bone tissue engineering: state of the art and future trends. Macromol Biosci 2004; 4: 743-65.

59. Siddappa R. et al. Cellular and Molecular Prerequisites for Bone Tissue Engineering. Ph.D Thesis. (accessed in december 2012 at http://doc.utwente.nl/58105/1/thesis_Siddappa.pdf?origin=publication detail)

60. Sava-Rosianu, et al. Alveolar bone repair using mesenchymal stem cells placed on granular scaffolds in a rat model. J. of nanomat. and biostruc. 2013; 8: 303-311.

61. Owen M, Friedenstein AJ, Stromal stem cells: marrowderived osteogenic precursors. Ciba Found Symp 1988; 136: 42-60.

62. Tang W, et al. White fat progenitor cells reside in the adipose vasculature. Science 2008; 322: 583-6.

63. Yu J, et al. Human induced pluripotent stem cells free of vector and transgene sequences. Science 2009; 324: 797-801.

64. Lemischka IR, Raulet DH, Mulligan RC. Developmental potential and dynamic behavior of hematopoietic stem cells. Cell 1986; 45: 917-27.
65. Pittenger MF, et al. Multilineage potential of adult human mesenchymal stem cells. Science 1999; 284: 143-7.

66. Undale AH, et al. Mesenchymal stem cells for bone repair and metabolic bone diseases. Mayo Clin Proc 2009; 84: 893-902.

67. Aziz Aly LA, et al. Influence of Autologus Adipose Derived Stem Cells and PRP on Regeneration of Dehiscence-Type Defects in Alveolar Bone: A Comparative Histochemical and Histomorphometric Study in Dogs. Int J Stem Cells 2011; 4: 61-9.

68. Tobita M, Mizuno H. Adipose-derived stem cells and platelet-rich plasma: the keys to functional periodontal tissue engineering. Curr Stem Cell Res Ther 2013; 8: 400-6.

69. Tobita M, et al. Periodontal tissue regeneration by combined implantation of adipose tissue-derived stem cells and platelet-rich plasma in a canine model. Cytotherapy 2013; 15: 1517-26.

70. Pourebrahim N, et al. A comparison of tissue-engineered bone from adipose-derived stem cell with autogenous bone repair in maxillary alveolar cleft model in dogs. Int J Oral Maxillofac Surg 2013; 42: 562-8.

71. Gurdon, J.B. and D.A. Melton, Nuclear reprogramming in cells. Science 2008; 322: 1811-5.

72. Takahashi K, et al. Induction of pluripotent stem cells from adult human fibroblasts by defined factors. Cell 2007; 131: 861-72.

73. $\mathrm{Yu} \mathrm{J}$, et al. Induced pluripotent stem cell lines derived from human somatic cells. Science 2007; 318: 1917-20.

74. Takahashi K, Yamanaka S. Induction of pluripotent stem cells from mouse embryonic and adult fibroblast cultures by defined factors. Cell 2006; 126: 663-76.

75. Cai J, et al. Dopaminergic neurons derived from human induced pluripotent stem cells survive and integrate into 6-OHDA-lesioned rats. Stem Cells Dev 2010; 19: 1017-23.

76. Tateishi K, et al. Generation of insulin-secreting isletlike clusters from human skin fibroblasts. J Biol Chem 2008; 283: 31601-7.

77. Zhang J, et al. Functional cardiomyocytes derived from human induced pluripotent stem cells. Circ Res 2009; 104: e30-41.

78. Arpornmaeklong P, et al. Phenotypic characterization, osteoblastic differentiation, and bone regeneration capacity of human embryonic stem cell-derived mesenchymal stem cells. Stem Cells Dev 2009; 18: 955-68.

79. Kuznetsov SA, Cherman N, Robey PG. In vivo bone formation by progeny of human embryonic stem cells. Stem Cells Dev 2011; 20: 269-87.

80. Silva J, et al. Promotion of reprogramming to ground state pluripotency by signal inhibition. PLoS Biol 2008; 6: 253.

81. Meijer GJ, et al. Cell-based bone tissue engineering. PLoS Med 2007; 4: 9.

82. Marolt D, Knezevic M, Novakovic GV. Bone tissue engineering with human stem cells. Stem Cell Res Ther 2010; $1: 10$. 